\title{
"Effects of the Covid-19 pandemic on employee income: A case study of the Vietnamese aviation industry"
}

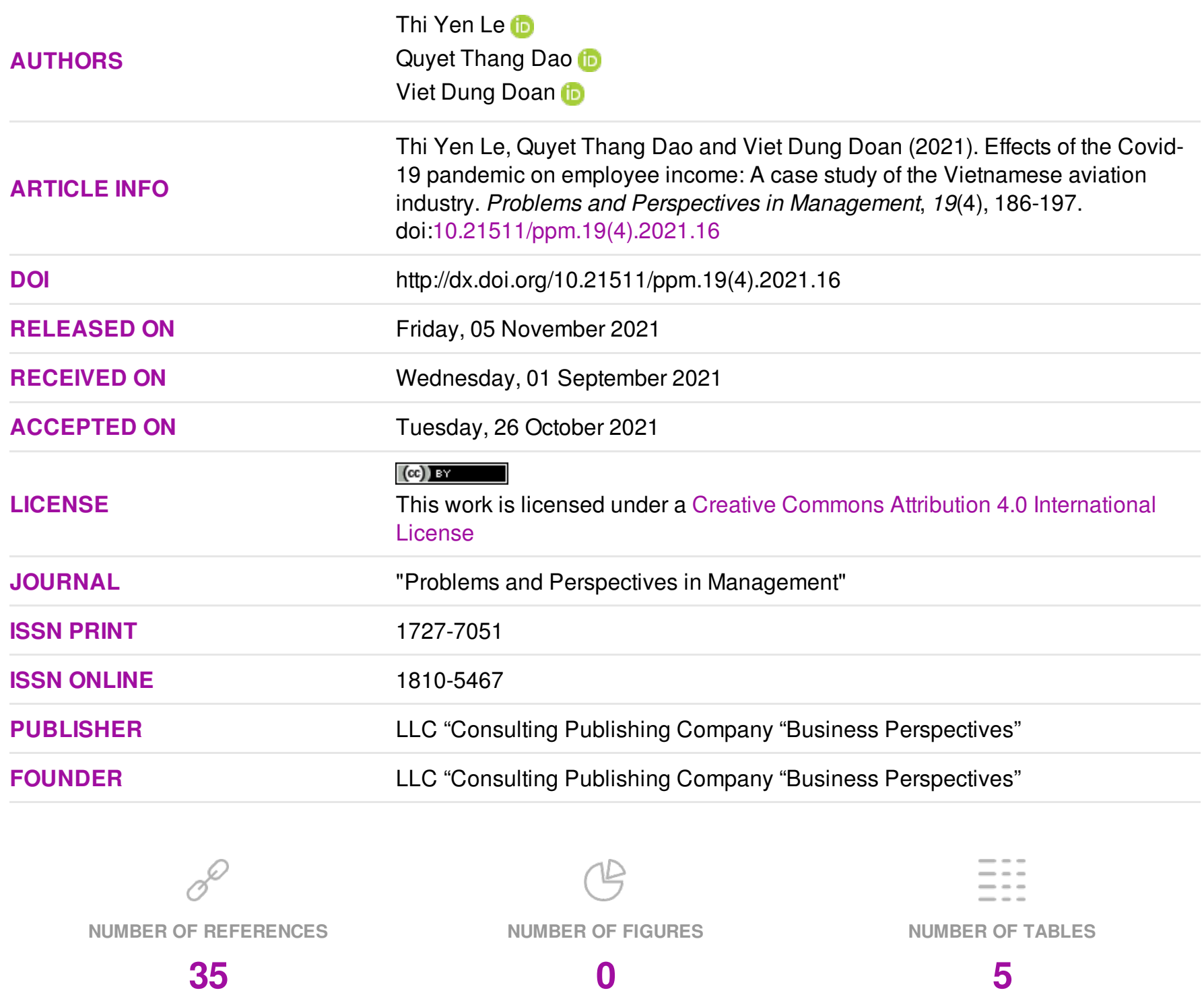

(C) The author(s) 2021. This publication is an open access article. 


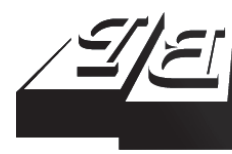

\section{BUSINESS PERSPECTIVES}

LLC "CPC "Business Perspectives" Hryhorii Skovoroda lane, 10, Sumy, 40022, Ukraine www.businessperspectives.org
Received on: $1^{\text {st }}$ of September, 2021 Accepted on: $26^{\text {th }}$ of October, 2021 Published on: $5^{\text {th }}$ of November, 2021

๑ Thi Yen Le, Quyet Thang Dao, Viet Dung Doan, 2021

Thi Yen Le, Dr., Lecturer, Hanoi Architectural University, Vietnam. (Corresponding author)

Quyet Thang Dao, Dr., Lecturer, Quy Nhon University, Vietnam.

Viet Dung Doan, Dr., Lecturer, National Economics University, Vietnam.

\section{EFFECTS OF THE COVID-19 PANDEMIC ON EMPLOYEE INCOME: A CASE STUDY OF THE VIETNAMESE AVIATION INDUSTRY}

\begin{abstract}
The objective of this study is to analyze the effects of the Covid-19 pandemic on the income of employees who work in the aviation sector in Vietnam. These workers are working in the field that has been most negatively affected by the Covid-19 outbreak. The study uses data collected from 280 Vietnamese employees working in the aviation industry. The pool OLS model is studied and used to analyze the influence of factors on the income of people who work in the aviation sector in Vietnam. The research results show that the Covid-19 pandemic has reduced the earnings of workers in the aviation sector (the effect factor is -5.576921 ); the income of workers is affected by many factors but in varying degrees such as a work area; gender; educational level; work experience; the number of jobs creating money; personal investments of the part of employees. At the same time, the research findings also show that the difference in the wages of employees in the aviation industry before and after the Covid-19 is vastly different (income difference is about 12.21 million $\mathrm{VND} /$ month).
\end{abstract}

Keywords

Covid-19, aviation sector, pool OLS model, change in income, new livelihood strategy

\section{JEL Classification O12, J22, O10}

\section{INTRODUCTION}

There have been devastating effects of the global Covid-19 pandemic on all countries, not only affecting health but also negatively affecting the economy and social security. For economies, the Covid-19 pandemic has caused difficulties for all actors involved in the economy, from large corporations to enterprises, and affects the employees directly involved in the production and business processes of enterprises (Suratman et al., 2021; Alessa et al., 2021; Nguyen \& Tran, 2021). Enterprises are a key link in the operation of the economy. The impact of the Covid-19 pandemic has created unwanted changes in businesses, production stagnation, high inventories, negative business results, and many of the companies had to declare bankruptcy or close production as well as stores for a long time (Obrenovic et al., 2020; Pattiruhu \& Paais, 2020; Shen et al., 2020). The effects of the Covid-19 pandemic on enterprises have led to direct consequences for employees working in those firms, as their lives are made harder, their incomes are reduced or even they became unemployed. Therefore, these caused adverse impacts on countries' social security.

In Vietnam, according to GSO (2020) statistics, with 126,565 firms surveyed to study the impacts of the Covid-19 pandemic on their production and business activities, nearly $86 \%$ of the surveyed enterprises answered that they were influential. However, the degree of influence 
was different between firms. In the group of enterprises most affected, there are companies in the service sector that are most affected by an estimated impact of $85.9 \%$. In the service sector, there are many affected industries in the first group, which is the aviation industry, whose estimated influence rate is $100 \%$. The impact of accommodation services is $97.1 \%$. Enterprises having difficulty in production and business activities have led to challenges for the employees. GSO (2021a) statistical results also reflect the current reality in Vietnam about the effect of Covid-19 on employees. The Covid-19 pandemic has affected 9.1 million workers, of which 540 thousand people lost their jobs. About 2.8 million people had to halt production and business temporarily. 3.1 million people have their working hours cut or forced to take time off or rotating leave.

The Covid-19 pandemic has caused negative effects on the employment of workers, in which the aviation sector is the most affected. Moreover, labor is one of the most crucial inputs of production, contributing significantly to the development of enterprises and the growth of economies. At the same time, the DFID (1999) Research Framework has pointed out that the income of workers will be affected by resources, at the same time under the influence of external factors such as natural disasters (e.g. epidemics). The Covid-19 pandemic is analyzed as a factor directly affecting the income of workers in the aviation industry, along with the study also on a variety of other factors affecting people's earnings in the context of Covid-19. Therefore, it is essential to analyze the effect of the Covid-19 pandemic on employees, directly the income of workers in the aviation sector, and ensure the representatives of the group of workers affected by the Covid-19 pandemic.

\section{LITERATURE REVIEW}

The Covid-19 pandemic have affected sectors and actors participate in the economy to varying degrees, studies have also approached different research directions and methods to analyze the influence of the Covid-19 pandemic. Qian and Fan (2020) and Bezerra et al. (2020) have consistently shown that the Covid-19 pandemic have negatively affected workers' incomes, thereby affecting their behaviors in society; social security in countries is also affected.

Qian and Fan (2020), using survey data on workers in China who have been impacted by the Covid-19 pandemic, apply a panel model to analyze the influence of factors under the impact of the Covid-19 pandemic on workers' income. The Covid-19 pandemic has caused a downturn in earnings in China and there is a relative difference. Specifically, research results have shown that, in the context of the Covid-19 pandemic, workers with different education levels will have different income levels; the gender of workers will also affect their income when Covid-19 occurs. The extent of the effect of the Covid-19 pandemic on employees is quantified from little affected; most affected and not affected on the basic salary applied in China. Meanwhile, Bezerra et al. (2020) used Brazilian research data to study changes in workers' incomes. Changes in income have forced workers to adjust their spending.

The Covid-19 pandemic has brought injuries to workers in many countries, acts as an agent affecting their earnings. As one of the agents of change, changing contexts have been studied in previous studies when examining changing contexts in countries, forcing workers to have new livelihood strategies to suit actual conditions (DFID, 1999; Bury, 2004; Cu et al., 2020; Dai et al., 2013). The studies all agree that any changes in the actual context will cause difficulties for people living in those affected localities or countries. Workers suffer from direct job injuries, which, if irreversible, will directly affect their income, and life challenges in terms of spending will also occur to them (Bui et al., 2013).

When researching on factors affecting people's income while life context changes, studies by Tran (2013), Nguyen and Bui (2011), Le (2007), Benayas et al. (2007), Bryceson (1996), and Jansen et al. (2006) aimed to compare people's incomes before and after changes. The research outcomes are consistent when it comes to the fact that the changing context will bring new opportunities for workers if they can adapt and will also be challenging if 
they can't. The changes in factors that affect people's income include education, gender, number of employees, etc.

When the context changes with natural disasters, epidemics, floods, mangroves, etc., workers will also have to adapt to new conditions and develop more appropriate livelihood strategies. Nelson et al. (2010) has calculated the adaptive capacity of people when there are changes in the context through calculating the vulnerability of people's livelihoods caused by the context (Adger et al., 2001; Le \& Le, 2020). These studies all use the sustainable livelihood analysis model of DFID (1999) as a theoretical framework for research; they have calculated people's adaptive capacity through resource groups that affect their livelihoods in the context of changes including human resources, physical resources, social resources, financial resources, and natural resources. From there, studies will measure the extent of the influence of injuries on people's income (Tu et al., 2012; Cu et al., 2020; Tu et al., 2015).

It is clear that the employment and income of workers are affected by the Covid-19 pandemic in particular and fluctuations due to external influences such as natural disasters, epidemics, floods, etc. However, the extent of the effects of Covid-19 on the employment and income of each worker is at different levels. Simultaneously, factors affecting workers' income are also different in the context of the Covid-19 pandemic. Given the position and role of labor in the economy, it is necessary to analyze the influence of the Covid-19 pandemic on employee incomes as well as the extent of the effect of factors on the earnings of workers in the context of the Covid-19 pandemic.

\section{AIMS}

Thus, by drawing on and developing previous studies, this study aims to reach the following aims. Firstly, the study analyzes factors that influence workers' incomes in the aviation sector - this is a sector particularly hard hit by the Covid-19 epidemic in Vietnam. Secondly, the study examines the difference in workers' incomes in the context of the Covid-19 pandemic by comparing the incomes of workers in the aviation sector before and after Covid-19, and the difference in wages between the employee groups by gender and by education level.

\section{METHODS}

\subsection{Data collection methods}

The study uses data collection through a survey of aviation workers in Vietnam based on the GSO (2021b) survey. The information collected includes sociological details of the surveyed subjects, information on the impact of Covid-19 on employee income and employment, and information on new livelihood strategies implemented by workers to cope with the difficulties caused by Covid-19.

The survey object is airline employees of Vietnam, specifically ensuring a balance between employees working in private airlines and workers employed in state-owned airlines. In addition, it is necessary to survey employees from all departments, including pilots, flight attendants, ground service staff, technical staff, office staff, and airline support staff.

Nguyen (2014) said that the number of observations required to perform statistical operations is 100 observations; thus, it is possible to conduct surveys to ensure the required number of samples when performing statistical operations. 400 questionnaires were distributed according to the following groups:

- 150 questionnaires surveyed employees working at Vietjet air - this is the largest private airline in Vietnam;

- 150 questionnaires surveyed employees working at Vietnam's national airline (Vietnam Airline) - this is Vietnam's largest state-invested airline.

With the remaining 200 questionnaires, the study surveyed the remaining airlines operating in Vietnam, such as VietTravel, Pacific Airline, private airlines, and seaplane airlines.

After distributing those 500 questionnaires, 325 questionnaires were collected, data entry was performed. 280 survey questionnaires met the 
requirements for complete survey information. With 280 samples of this survey, corresponding to 280 observations, it has met the minimum number of observations to perform statistical operations.

The data were collected from January to the end of April 2021. The survey was sent directly to the selected employee groups. In some cases, due to the effect of the Covid-19 pandemic, social distancing took place, so the ballots were sent by both methods, which is to send directly and then online via email to have responses from a variety of target employees.

At the same time, this study carried out focus group discussions with two groups of employees representing employees working in private airlines and state airlines. The findings of the group discussions helped collect more multi-dimensional perspectives and additional data for the quantitative analysis. Focus group discussions took place on June 8, 2021. Each group of workers joined in a focus group discussion consisting of 4 people, with discussion questions revolving around the specific impact of Covid-19 on the income and employment of employees and the new strategies they have implemented to cope with the difficulties brought by Covid- 19 .

\subsection{Data analysis methods}

With the collected data, the POOL OLS regression model is used to analyze the influence of factors on employee income in the aviation sector in the context of the Covid-19 pandemic. The variables selected for use in the study include dependent and independent variables.

\subsubsection{Dependent variable}

Income of employees in the aviation sector $(\mathrm{Y})$ : This income is measured as the total income of employees in each month; the unit is million VND/ month/employee. The study inherits the findings of Tran (2013), Qian and Fan (2020), Bezerra et al. (2020), and Nguyen and Bui (2011). At the same time, for a more detailed analysis of employee income sources, two groups of income (investments and income from salary and allowance) were distinguished.

\subsubsection{Independent variables}

Gender of employees in the aviation sector (GEND): This is a scale to measure the influence of gender on income, which includes male and female workers in the aviation sector. This variable is inherited from Qian and Fan (2020), Bezerra et al. (2020), Nguyen and Bui (2011), Tuyen and Huong (2014), and Huynh and Mai (2011).

Education level (EDU): Education level influences jobs, each job position has different requirements in terms of education level, the higher position requires the higher the income, and vice versa. This variable is inherited from Qian and Fan (2020), Bezerra et al. (2020), Nguyen and Bui (2011), Cu and Nguyen (2021), Tuyen and Huong (2014), where the studies split education levels including college, undergraduate, and graduate degrees. The majority of positions in Vietnam's airlines, however, require a university degree to qualify for recruitment. This situation was discovered during the survey. Therefore, inheriting previous studies and adjusting the scales to suit the actual research context, educational qualifications are divided into undergraduate $(\mathrm{DH})$ and postgraduate $(\mathrm{SDH})$ qualifications.

Work experience (Exper): The scale represents the working time of employees at the same position, the unit of measurement for this variable is the number of working years. This variable is inherited from Nguyen and Bui (2011).

Work area (LHLV): This variable can be used to identify employees working at state-owned airlines and employees working at private airlines. This variable is inherited from Qian and Fan (2020) and Bezerra et al. (2020).

Individual investments of employees (Invest): It is the amount of money that employees use to invest to have additional incomes in a month or a year; the unit of calculation for this investment is million dongs. This variable is inherited from Qian and Fan (2020), Bezerra et al. (2020), and Huynh and Mai (2011).

Cost of living of employees (Cost): It is an expense that employees use to pay for their monthly living expenses. This cost is calculated in millions of 
$\mathrm{VND} /$ month. This variable is inherited from Qian and Fan (2020), Bezerra et al. (2020), Tran (2013), and Siegel (2005).

Number of income-generating activities of employees (Nincom): It is the number of jobs generating income for employees in the aviation sector, including main jobs, part-time jobs such as investment, seasonal jobs according to orders, etc. This variable is inherited from the study of Nguyen and Bui (2011).

Covid-19: This is a variable that reflects the influence of Covid-19 on the income of workers in the aviation sector (as a dummy variable). When comparing the impacts of the Covid-19 pandemic on the job and earnings of workers in the aviation sector in Vietnam, 2020 is taken as the starting point of the Covid-19 pandemic in Vietnam. This variable is inherited from Qian and Fan (2020), Bezerra et al. (2020), and Nguyen and Tran (2021).

At the same time, this study also uses the T-test to test the difference in employee earnings to examine the difference in income of aviation workers before and after the Covid-19 pandemic; the difference in earnings of aviation workers by gender during the Covid-19 pandemic; and the difference in income of aviation workers by education level when affected by Covid-19.

\section{RESULTS}

With the data collected from the survey of employees working at Vietnam's airlines, the study analyzed data to identify the effects of the Covid-19 pandemic on workers' incomes. First, the study performed descriptive statistical analysis on the observations (Table 1).

Regarding the scale of the work area of the surveyed workers, it shows that of the total 280 surveyed employees, 160 employees work for private airlines, accounting for about $57.1 \%$ of the overall sample of observations, and 120 observations are employees working in the public sector. Vietjet Air, Vietravel, and other private airlines offer jetliners and seaplanes as part of Vietnam's private airline industry. Meanwhile, state-owned airlines and state-owned shares include Vietnam's national airline (Vietnam airline) and Pacific Airline. The balance in the surveyed subjects will ensure a more diverse and accurate perspective while analyzing research results.

Regarding the gender of employees, airlines have multiple divisions, and the requirements for gender also vary. From the employees surveyed, there were 200 male employees, accounting for about $71.4 \%$ of the total surveyed employees, the rest are female.

The education level of employees working at airlines in Vietnam is relatively high. Airlines have strict requirements on qualifications and specialties suitable for the position they are recruiting for. Before the Covid-19 pandemic took place, 280 employees working at surveyed airlines have university degrees. However, after the Covid-19 pandemic took place, a part of employees at airlines have had to take unpaid leave or cut jobs, a part of them have chosen the form of supplementing knowledge at the graduate level. Thus, out of

Table 1. Descriptive statistics of the study's variables

\begin{tabular}{|c|c|c|c|c|c|}
\hline & \multirow{2}{*}{ Items } & \multicolumn{2}{|c|}{ Covid $-19=0$} & \multicolumn{2}{|c|}{ Covid-19 = 1} \\
\hline & & Count & Column N, \% & Count & Column N, \% \\
\hline \multirow{2}{*}{ LHLV } & Private sector & 160 & $57.1 \%$ & 160 & $57.1 \%$ \\
\hline & State secretary & 120 & $42.9 \%$ & 120 & $42.9 \%$ \\
\hline \multirow{2}{*}{ GEND } & Female & 80 & $28.6 \%$ & 80 & $28.6 \%$ \\
\hline & Male & 200 & $71.4 \%$ & 200 & $71.4 \%$ \\
\hline \multirow{2}{*}{ EDU } & $\mathrm{DH}$ & 280 & $100.0 \%$ & 240 & $85.7 \%$ \\
\hline & $\mathrm{SDH}$ & 0 & $0.0 \%$ & 40 & $14.3 \%$ \\
\hline \multirow{5}{*}{ NINCOM } & 1.0 & 1 & $.4 \%$ & 168 & $60.0 \%$ \\
\hline & 2.0 & 121 & $43.2 \%$ & 57 & $20.4 \%$ \\
\hline & 3.0 & 116 & $41.4 \%$ & 46 & $16.4 \%$ \\
\hline & 4.0 & 2 & $.7 \%$ & 9 & $3.2 \%$ \\
\hline & 5.0 & 40 & $14.3 \%$ & 0 & $0.0 \%$ \\
\hline
\end{tabular}


a total 280 surveyed workers, there were 40 workers (accounting for about $14.3 \%$ of the employees) who had postgraduate qualifications. This is proof that the educational requirements of workers in the aviation field are very high, especially the requirements for foreign languages, information technology, and soft skills.

Regarding the number of jobs generating income for employees at airlines, it was found that these workers not only have main jobs at airlines, which they call "right-hand" jobs, they also have parttime jobs and other income-generating jobs that are called "side-by-side" jobs. These jobs are relatively common and are frequently performed by employees working at airlines to earn extra income.

Before the Covid-19 pandemic took place, out of a total 280 employees surveyed, $0.4 \%$ of employees only have jobs at airlines that generate income for them; 121 surveyed employees, equivalent to $43.2 \%$, are employees with two income-generating activities; the number of employees with three income-generating activities accounts for about $41.4 \%$ of the surveyed employees; the remaining 42 surveyed workers have from 4 to 5 income-generating activities.

Meanwhile, the Covid-19 pandemic has significantly affected the number of income-generating activities for workers at airlines. Their income-generating work has decreased sharply, and the number of main income-generating activities for surveyed workers is only one job, which is usually a job at an airline. While, there are 57 employees, accounting for about $20.4 \%$ of the number of employees surveyed, with two income-generating activities.

Table 2. The descriptive statistics results

\begin{tabular}{l|c|c|c|c}
\hline \multirow{2}{*}{ Items } & \multicolumn{2}{c|}{ Covid-19=0 } & \multicolumn{2}{c}{ Covid-19=1 } \\
\cline { 2 - 5 } & Mean & $\begin{array}{c}\text { Standard } \\
\text { deviation }\end{array}$ & Mean & $\begin{array}{c}\text { Standard } \\
\text { deviation }\end{array}$ \\
\hline Invest & 57.886 & 57.418 & 45.641 & 43.760 \\
\hline Cost & 8.760 & 3.091 & 5.428 & 2.566 \\
\hdashline Y1 & 15.944 & 3.409 & 4.567 & 1.288 \\
\hline Y2 (invest) & 3.195 & 3.388 & 2.362 & 2.616 \\
\hdashline$Y$ & 19.139 & 6.360 & 6.929 & 2.814 \\
\hline
\end{tabular}

According to the results of descriptive statistics on the employee income, the income of airline employees before the Covid-19 outbreak was relative- ly high, about 19,139 million/month per employee. It is completely consistent with the fact of dynamism as well as diversity in income-generating activities for employees working at airlines. When the Covid-19 pandemic occurred, the income of workers in the aviation sector has been significantly reduced; the main income from aviation jobs has been cut from 50 to $80 \%$ of total income, other jobs such as business or other part-time jobs were also canceled or there was a drastic reduction in income. This leads to the average earnings of employees falling to about 6,929 million VND/month.

For the earnings of employees working at airlines, the study has broken down to see the sources of income. The employee income is distributed from two main sources. The first is investments, which often come from online business activities and securities. These investments bring a relatively stable income for employees, there is not much fluctuation between before and after Covid-19. Before Covid-19, revenue from this type of activity accounted for about 3,195 million VND/month on average. While after Covid-19 took place, this investment income has decreased, but it is relatively small compared to the general difficulties that Covid-19 causes to the whole economy as well as to workers; their earnings due to investment activity decreased to an average of about 2,362 million $\mathrm{VND} / \mathrm{month}$. Regarding the income from the main job at the airlines and other allowances that have brought a high part in the total income of the employees, however, the Covid-19 pandemic caused serious and negative influence on the wages of aviation employees. Before Covid-19 took place, the average income from this source was about 15,944 million VND/month. However, after Covid-19 their income has plummeted to an average of only about 4,567 million $\mathrm{VND} /$ month.

Workers' investments have remained relatively stable despite a decline due to the impacts of the Covid-19 pandemic. Before Covid-19, the average employee budget was about 57,886 million VND; this number decreased to an average of 45,641 million VND.

The incomes of workers in the aviation sector have decreased drastically, resulting in a decrease in their spending in daily life. In Vietnam, the average income of aviation workers before Covid-19 
Table 3. Results of regression models

\begin{tabular}{|c|c|c|c|c|}
\hline \multicolumn{5}{|c|}{ POOL OLS Robust } \\
\hline $\mathbf{Y}$ & Coef. & Std. err. & $\mathbf{z}$ & $\mathbf{P}>\mathbf{Z}$ \\
\hline Covid-19 & -5.576921 & 0.5259555 & -10.6 & 0.000 \\
\hline \multicolumn{5}{|c|}{ LHLV } \\
\hline - State Secretary & 2.740795 & 0.2570586 & 10.66 & 0.000 \\
\hline \multicolumn{5}{|c|}{ Gend } \\
\hline - Male & 2.460824 & 0.1389858 & 17.71 & 0.000 \\
\hline \multicolumn{5}{|c|}{ Edu } \\
\hline$-\mathrm{DH}$ & 0.9156483 & 0.3918685 & 2.340 .019 & 0.148 \\
\hline Exper & -0.2444245 & 0.0431614 & -5.66 & 0.000 \\
\hline Nincom & -1.421584 & 0.1471244 & -9.66 & 0.000 \\
\hline Invest & 0.0473649 & 0.0022879 & 20.7 & 0.000 \\
\hline Cost & 1.244197 & 0.0495374 & 25.12 & 0.000 \\
\hline Covid·Exper & -0.1299514 & 0.0611402 & -2.13 & 0.034 \\
\hline Covid.Nincom & 1.946759 & 0.1747631 & 11.14 & 0.000 \\
\hline Covid.Invest & -0.0383096 & 0.0022513 & -17.02 & 0.000 \\
\hline Covid.Cost & -0.6749145 & 0.075463 & -8.94 & 0.000 \\
\hline cons & 7.403505 & 0.7269384 & 10.18 & 0.000 \\
\hline sigma_u. & 2106735 & - & - & - \\
\hline sigma_e & 0.40760396 & - & - & - \\
\hline rho. & 21082279 & \multicolumn{3}{|c|}{ (fraction of variance due to $u_{-} i$ ) } \\
\hline$R 2$ & 0.9852 & \multicolumn{2}{|c|}{ Number of obs } & 560 \\
\hline Wald chi2(12) & $65,734.950$ & \multicolumn{2}{|c|}{ Prob > chi2 } & 0.000 \\
\hline
\end{tabular}

was among the highest among industries. This is called the "luxury" industry, which is very demanding for employees in terms of expertise, skills, and appearance. However, when Covid-19 took place, their income decreased, their spending was also affected. Before Covid-19, the average expenditure of employees was about 8.76 million $\mathrm{VND}$ /month, which has decreased to about 5,428 million VND/month.

Following that, the study carried out a regression analysis to measure the influence of factors on workers' income in the context of Covid-19 (Table 3).

All variables in the model are statistically significant at the $5 \%$ level of significance. The degree of influence of variables on the income of employees in the aviation sector under the effects of the Covid-19 pandemic is further analyzed.

The Covid-19 pandemic has reduced the income of workers in the aviation sector, the Coef coefficient of the Covid-19 variable is -5.576921 . This reflects the reality of the severe effects of the Covid-19 pandemic on workers: they lost their jobs, had to take unpaid leave, and reduce their direct income. These results support the views of Qian and Fan (2020) and Bezerra et al. (2020).
In Vietnam, the work area of aviation sector employees includes those working in state-owned enterprises, as well as those working in private enterprises. The results show that the coefficient of the variable LHLV is 2.740795 , which indicates a difference of 2.740795 between the influence level of workers in the public sector and those in the private sector; the group of workers working in the public sector has a better degree of positive influence on income than the group working in the private sector. These results support the views of Qian and Fan (2020) and Bezerra et al. (2020). Indeed, the research results also show that employees working in private firms often have to face higher levels of pressure and stay without support; workers often have to accept unpaid leave or enjoy $30-50 \%$ of the basic salary of the labor contract. Meanwhile, employees of state-owned enterprises always receive a minimum wage depending on regulations; the government supports these enterprises in their activities. When there are fluctuations due to external circumstances such as natural disasters or epidemics, employees working in the public sector are guaranteed a better income than those working in the private sector.

Regarding the gender variable (GEND), the results show that, in the context of the Covid-19 pandemic, 
a part of employees had to rotate jobs and perform activities other than their usual work at airlines. As the Covid-19 pandemic unfolded, airlines have had difficulty transporting passengers and have turned to more cargo transportation. Therefore, now procedures and operations by airlines often need the services of men, so the male gender in the aviation industry has a positive influence on income and is higher than that of female airline employees. This variable's coefficient is 2.460824; these outcomes support the views of Qian and Fan (2020), Bezerra et al. (2020), and Nguyen and Bui (2011).

The level of education of employees working at airlines (EDU) positively affects their income, when the level of labor meets the requirements, their income will also change positively and vice versa. The research results show that the necessary qualifications for workers working in the aviation field are university degrees; for workers with a university degree, the difference in the impact on workers' income compared to other groups is about 0.9156483 . The results of the study support the views of Qian and Fan (2020), Bezerra et al. (2020), Nguyen and Bui (2011), and Cu and Nguyen (2021).

Regarding work experience of employees (Exper), results show that work experience did not affect an employee income before the Covid-19 pandemic happened in the aviation sector. The coefficient of this variable is about -0.244245 . When participating in the aviation field, employees all undergo rigorous training courses, and only when they pass the tests they have the opportunity to work at airlines. According to the survey results, airlines rely more on ability and job performance while paying wages instead of depending on work experience. While, after the influence of the Covid-19 pandemic, work experience negatively affects workers' incomes; the experience does not work in the context of the Covid-19 pandemic, and the wages of workers decreased: $-0.2444245-0.1299514$. The difference in the influence of work experience before and after Covid-19 is -0.1299514 . These outcomes do not support the views of Nguyen and Bui (2011).

The number of jobs generating income (NINCOM) of workers has drastically decreased, which affects the earnings of workers, the Coef coefficient of the
NINCOM variable is -1.421584 , which shows that before the Covid-19 pandemic, the number of income-generating activities of employees has a negative relationship with income. The difference in benefits of the employee's job creation margin before and after Covid-19 changed the employee's income by 1.946759 . The total impact of the number of post-Covid-19 job creation activities on workers' incomes is $-1.421584+1.946759$. The results do not support the views of Nguyen and Bui (2011). In fact, in the context of the Covid-19 pandemic, employees of airlines often have to rotate jobs and look for part-time jobs to maintain income and life level while the main earnings from the salaries of airlines are cut and there are not enough guarantees. Their income has therefore also changed according to the level of adaptation and change of work. The jobs workers have done during Covid-19 are investing in stocks, finding part-time jobs, selling online to earn extra income, etc.

As for individual investments of employees (Invest), before the Covid-19 pandemic, individual investments made by airline employees produced income that positively affected worker income. The coefficient of this variable after the calculation is 0.0473649 . This result supports the views of Qian and Fan (2020), Bezerra et al. (2020), and Huynh and Mai (2011). However, when the Covid-19 pandemic took place, the investments of workers in the aviation sector were more difficult due to the limitations of goods and the higher accumulation of customers as trade becomes more difficult. The difference in the effect of personal investment before and after Covid-19 shows a negative impact on workers' income, Coef. coefficient $=-0.0383096$. The total influence of post-Covid-19 individual earnings on workers' wages is $0.0473649-0.0383096$.

Cost of living of employees (Cost) is an expense that employees use to pay for their monthly living expenses. This cost is calculated in millions of $\mathrm{VND} /$ month. The results of data analysis show that the higher the cost of living, the higher the income of workers and vice versa. The coefficient of the cost variable before Covid-19 is about 1.244197, which shows that the cost of living has a positive effect on income. The research results support the views of Qian and Fan (2020), Bezerra et al. (2020), Tran (2013), and Siegel (2005). However, after 
Table 4. Difference in income under the impact of Covid-19

\begin{tabular}{|c|c|c|c|c|c|c|}
\hline \multirow{2}{*}{\multicolumn{2}{|c|}{ Items }} & \multicolumn{2}{|c|}{ Paired differences } & \multirow{2}{*}{$\mathbf{t}$} & \multirow{2}{*}{ df } & \multirow{2}{*}{ Sig. (2-tailed) } \\
\hline & & Mean & Std. deviation & & & \\
\hline Pair 1 & $Y \_A-Y \_B$ & -12.210 & 4.339 & -47.085 & 279.000 & 0.000 \\
\hline
\end{tabular}

Covid-19 occurred, the cost of living of employees working at airlines has plummeted to maintain their lives. The total impact of the post-Covid-19 costs of living is $1.244197-0.6749145$. The difference in the influence before and after Covid-19 of the cost of living on the income of employees in the aviation sector is -0.6749145 (Table 4 ).

To consider the impact of Covid-19 on employee incomes, the study used the T-test to compare the earnings of aviation sector employees before and after Covid-19. The calculations show a difference between workers' incomes in the aviation industry before and after Covid-19; the income of those working in the aviation industry after Covid-19 decreased by about $-12,210$ million VND per month.

The results of the focus group discussions also show the difficulties caused by the Covid-19 pandemic for employees. The first part of the workers mentioned that after the Covid-19 pandemic started, they had to take continuous unpaid leave for a period of 2-3 months each; when the Covid-19 pandemic was under control, they were allowed to return to work. However, the situation only stabilized for 1-2 months before a new wave of Covid-19. There are constant flight cancellations, workers are on unpaid leave, and anxiously waiting for an announcement by the company. During the period of leave, the employee has no income; workers maintain their lives with previously accumulated money and find other seasonal jobs to earn a living.
In addition, the second part indicated that during the Covid-19 pandemic, workers still have income-generating jobs: those are investment activities, and rotation to serve flights as assigned by the company. However, their income decreased by about $50-60 \%$ compared to the time before the Covid-19 pandemic took place. Despite the hardship, they still accept and are satisfied with the current income level in the context of the complicated Covid-19 pandemic, maintaining a source of income and staying happy with their job.

The third group of comments shows that workers are not greatly affected by the shutdown because they are still paid, their work is still going on. This group of workers works in state-owned aviation companies, their income is still guaranteed as the basic salary to sustain life.

However, the most common thing for the surveyed workers is that they all feel that their life is becoming more difficult, and their income dropped sharply due to the impact of the Covid-19 pandemic. Besides, difficulties caused by Covid-19 in terms of employment position as well as health also affect their lives.

The study examined the difference in worker earnings by working area, by gender, and by education level (Table 5).

The process of group discussions also showed that while the risks posed by context such as the Covid-19 pandemic, it seems that workers in the

Table 5. Independent samples test

\begin{tabular}{|c|c|c|c|c|c|c|c|c|}
\hline \multicolumn{2}{|c|}{ Items } & \multicolumn{2}{|c|}{$\begin{array}{l}\text { Levene's test } \\
\text { for equality of } \\
\text { variances }\end{array}$} & \multicolumn{5}{|c|}{$t$-test for equality of means } \\
\hline & & $\mathbf{F}$ & Sig. & $\mathbf{t}$ & df & $\begin{array}{c}\text { Sig. } \\
\text { (2-tailed) }\end{array}$ & $\begin{array}{c}\text { Mean } \\
\text { difference }\end{array}$ & $\begin{array}{l}\text { Std. error } \\
\text { difference }\end{array}$ \\
\hline $\begin{array}{l}\text { Y_A (State Secretary- } \\
\text { Private Sector) }\end{array}$ & $\begin{array}{l}\text { Equal variances } \\
\text { not assumed }\end{array}$ & 350.835 & 0.000 & 17.520 & 138.774 & 0.000 & 4.329 & 0.247 \\
\hline Y_A (Male-Female) & $\begin{array}{l}\text { Equal variances } \\
\text { not assumed }\end{array}$ & 62.880 & 0.000 & 17.152 & 253.089 & 0.000 & 3.541 & 0.206 \\
\hline$Y_{-} A(S D H-D H)$ & $\begin{array}{l}\text { Equal variances } \\
\text { not assumed }\end{array}$ & 69.010 & 0.000 & 0.421 & 243.651 & 0.674 & 0.083 & 0.197 \\
\hline
\end{tabular}


public and state-funded sectors are "safer" than those employed in the private sector. Workers working in the public sector are supported by the state and guaranteed a minimum income to sustain their lives. While in private enterprises workers do not receive these direct supports. The survey results show that the wages in the state sector are higher than that of workers in the private sector by about 4,329 million/month.

Due to the peculiarities of the aviation industry and the conditions of the Covid-19 pandemic, airline service staff performs tasks as assigned as the airline shifts from focusing on passengers to focusing on goods on demand when flights are canceled. For those serving on these cargo flights, airlines give priority to men. Those are typical examples in the current challenging context of the Covid-19 pandemic for workers in the aviation sector. The income of male employees in the aviation sector is about 3,541 million/month higher than female employees.

Study findings show almost no difference in income between workers with different education qualifications in aviation enterprises. Among aviation companies in Vietnam, the employees who are recruited require basic qualifications and skills, fully meeting the standards of the vacancy. When paying for employees, they are based on their position and their completion level. Therefore, the income of employees at airline companies is less affected by the difference in qualifications.

\section{DISCUSSION}

The ongoing Covid-19 pandemic has significantly adversely affected incomes in the aviation sector in Vietnam, which is the hardest hit among industries. To limit the negative effects of Covid-19 on people's income, some recommendations are proposed.

Firstly, airline employees must be proactive in dealing with negative impacts caused by external factors, preparing plans to be able to maintain their lives and change current jobs. In addition, employees need to have multi-disciplinary knowledge and skills to be able to adapt to new working positions as assigned by enterprises or in case it is necessary to find a new job to maintain life level when the work at the airlines has not improved.

Secondly, local authorities need to provide assistance to support workers who have lost their jobs and are in difficult circumstances during the Covid-19 pandemic. Although the Vietnamese government has implemented support packages for workers, these support packages have not been sufficient and timely for workers who face difficult conditions. Moreover, governments at all levels need to have supportive policies for enterprises in the aviation sector. Only when firms are "healthy" workers have a stable income and jobs, reducing unemployment and other injuries to society.

Third, enterprises also need plans and solutions to support employees, so that they can maintain a minimum life level; this way, enterprises can retain employees. They should avoid situations when employees are forced to quit their jobs. After the Covid-19 pandemic is under control, the airline's flight operations will be restored but there is a chance that there will be not enough workers to operate.

\section{CONCLUSION}

Based on the study's findings, the Covid-19 pandemic has caused difficulties for workers in the aviation sector and reduced their incomes. The research results have achieved the goal to analyze the influence of the Covid-19 pandemic on the earnings of workers in the aviation sector studying the effects through variables such as gender, education level, work experience, the working area of labor, investment of workers, cost of living, and especially the dummy variable of Covid-19. The study also showed the difference in employee income before and after Covid-19. Specifically, wages of workers decreased significantly after the Covid-19 started. Calculation results show that there is a difference in the income of those who work in aviation after the Covid-19 takes place; the earnings of airline employees decreased by about $-12,210$ million VND per month. Comparing the difference in workers' earnings by working 
sector, earnings in the state sector are higher than that of workers in the private sector by about 4,329 million/month. The findings of the study show no difference in income of employees in the aviation sector by qualification level.

\section{AUTHOR CONTRIBUTIONS}

Data curation: Thi Yen Le.

Formal analysis: Quyet Thang Dao, Viet Dung Doan.

Funding acquisition: Thi Yen Le.

Investigation: Thi Yen Le, Quyet Thang Dao.

Methodology: Thi Yen Le, Viet Dung Doan.

Resources: Thi Yen Le, Quyet Thang Dao, Viet Dung Doan.

Software: Quyet Thang Dao, Viet Dung Doan.

Writing - original draft: Thi Yen Le, Quyet Thang Dao.

Writing - review \& editing: Thi Yen Le.

\section{REFERENCES}

1. Adger, W. N., Kelly, P. M., \& Ninh, N. H. (2001). Environment, Society and precipitous change. In Living with environmental change: social vulnerability, adaptation and resilience in Vietnam (pp. 3-18). London: Routledge.

2. Alessa, A. A., Alotaibie, T. M., Elmoez, Z., \& Alhamad, H. E. (2021). Impact of COVID-19 on Entrepreneurship and Consumer Behaviour: A Case Study in Saudi Arabia. The Journal of Asian Finance, Economics and Business, 8(5), 201-210. https://doi.org/10.13106 jafeb.2021.vol8.no5.0201

3. Benayas, J. M. R., Martins, A., Nicolau, J. M., \& Schulz, J. J. (2007). Abandonment of agricultural land: An overview of drivers and consequences. CAB Reviews: Perspectives in Agriculture, Veterinary Science, Nutrition and Natural Resources, 2(57), 1-14. https://doi.org/10.1079/PAVSNNR20072057

4. Bezerra, A. C. V., Silva, C. E. M. D., Soares, F. R. G., \& Silva, J. A. M. D. (2020). Factors associated with people's behavior in social isolation during the Covid-19 pandemic. Ciencia \& Saude Coletiva, 25(suppl1), 2411-2421. https://doi.org/10.1590/141381232020256.1.10792020

5. Bryceson, D. F. (1996). Deagrarianization and rural employment in sub-Saharan
Africa: A sectoral perspective. World Development, 24(1), 97-111. https://doi.org/10.1016/0305750X(95)00119-W

6. Bui, T. M. H., Schreinemachers, P., \& Berger, T. (2013). Hydropower development in Vietnam: Involuntary resettlement and factors enabling rehabilitation. Land Use Policy, 31, 536-544. https://doi.org/10.1016/j.landusepol.2012.08.015

7. Bury, J. (2004). Livelihood in transition: Transnational gold mining operation and local change in Cajamarca, Peru. The Geographical Journal, 170(1), 78-91. https://doi.org/10.1111/j.00167398.2004.05042.x

8. $\mathrm{Cu}, \mathrm{T} . \mathrm{T} .$, \& Nguyen, T. A. (2021). Development of industrial parks and a new livelihood strategy for the people in Vietnam. Problems and Perspectives in Management, 19(1), 221-230. http://dx.doi.org/10.21511/ ppm.19(1).2021.19

9. $\mathrm{Cu}$, T. T., Hoang, T. H. H., \& Le, T. Y. (2020). Impacts of Industrial Park Development on the Surroundings' Livelihood. The Journal of Asian Finance, Economics, and Business, 7(9), 737-746. https:// doi.org/10.13106/jafeb.2020.vol7. no9.737

10. Dai, D., Le, N., \& Nguyen, T. D. (2013). Difficulties in transition among livelihood under agricultural land conversion for industrialization: Perspective of human development, Mediterranean Journal of Social Sciences, 4(10), 259-267. http:// dx.doi.org/10.5901/mjss.2013. v4n10p259

11. DFID. (1999). Sustainable livelihood guidance sheets. London: DFID. Retrieved from https://www. livelihoodscentre.org/-/sustainablelivelihoods-guidance-sheets

12. GSO. (2020). Report the influence of Covid-19 on enterprises. Retrieved from https://www.gso.gov.vn/dulieu-va-so-lieu-thong-ke/2020/07/ toa-dam-danh-gia-tac-dong-cuadai-dich-covid-19-den-doanhnghiep-viet-nam/

13. GSO. (2021a). Report the influence of Covid-19 on laborers' income and employment. Retrieved from https://www.gso.gov.vn/du-lieuva-so-lieu-thong-ke/2021/04/ bao-cao-tac-dong-cua-dich-covid19-den-tinh-hinh-lao-dong-vieclam-quy-i-nam-2021/

14. GSO. (2021b). Survey on the impact of Covid-19 on enterprises and labors. Hanoi, Vietnam: General Statistics Office. Retrieved from https://www. gso.gov.vn/du-lieu-va-so-lieuthong-ke/2021/09/bao-cao-laodong-viec-lam-quy-1-nam-2021/

15. Huynh, T. D. X., \& Mai, V. N. (2011). Phan tich cac yeu to anh huong den thu nhap cua ho chan nuoi gia 
cam o dong bang song cuu long [Analysis of factors affecting the income of poultry farmers in the Mekong Delta]. Scientific Journal, 17(b), 87-96. (In Vietnamese).

16. Jansen, H. G. P., Pender, J., Damon, A., Wielemaker, W., \& Schipper, R. (2006). Policies for sustainable development in the hillside areas of Honduras: A quantitative livelihoods approach. Agricultural Economics, 34(2), 141-153. https://doi.org/10.1111/j.15740864.2006.00114.x

17. Le, D. P. (2007). Thu nhap, doi song, viec lam cua nguoi dan co dat bi thu hoi de xay dung cac khu cong nghiep, khi do thi ket cau ha tang kinh te-xa hoi cac cong trinh phuc vu loi ich quoc gia [Income, life, work of people whose land is acquired to build industrial parks, urban areas of socio-economic infrastructure, projects serving national interests]. (In Vietnamese). Hanoi: National Political Publishing House.

18. Le, L. H., \& Le, T. N. (2020). Determinants of Income Diversification among Rural Households in the Mekong River Delta: The Economic Transition Period. The Journal of Asian Finance, Economics and Business, 7(5), 291-304. https://doi.org/10.13106/ jafeb.2020.vol7.no5.291

19. Le, T., Pham, V., Cu, T., Pham, M., \& Dao, Q. (2020). The effect of industrial park development on people's lives. Management Science Letters, 10(7), 1487-1496. https://doi. org/10.5267/j.msl.2019.12.018

20. Nelson, R., Kokic, P., Crimp, S., Martin, P., Meinke, H., Howden, S. M., Voil, P. D., \& Nidumolu, U. (2010). The vulnerability of Australian rural communities to climate variability and change: Part II - integrating impacts with adaptive capacity. Environmental Science \& Policy, 13(1), 18-27. https://doi.org/10.1016/j.envsci.2009.09.007

21. Nelson, R., Kokic, P., Elliston, L., \& King, J. A. (2005). Structural adjustment: a vulnerability index for Australian broadacre Agriculture. Australian Commodities, 12(1), 171179. Retrieved from https://search. informit.org/doi/abs/10.3316/informit.090810822935498
22. Nguyen, H. N., \& Tran, M. D. (2021). The Effect of Perceived Organizational Support on Employee Engagement During the COVID-19 Pandemic: An Empirical Study in Vietnam. The Journal of Asian Finance, Economics and Business, 8(6), 415-426. https:// doi.org/10.13106/jafeb.2021.vol8 no6.0415

23. Nguyen, Q. N., \& Bui, V. T. (2011). Cac yeu to anh huong den thu nhap cua nguoi dan toc thieu so o vung dong bang song cuu long [Factors affecting the income of ethnic minorities in the Mekong Delta]. Science Journal, 18(a), 240-250. (In Vietnamese).

24. Nguyen, V. T. (2014). Giao trinh thuc hanh nghien cu trong kinh te va quan tri kinh doanh [Curriculum of research practice in economics and business administration]. National Economics University Publishing House. (In Vietnamese). Retrieved from https://vietbooks.info/threads/ giao-trinh-thuc-hanh-nghiencuu-trong-kinh-te-va-quan-trikinh-doanh-nguyen-van-thang283-trang.96134/

25. Obrenovic, B., Du, J., Godinic, D., Tsoy, D., Khan, M. A. S., \& Jakhongirov, I. (2020). Sustaining enterprise operations and productivity during the Covid-19 pandemic: "Enterprise Effectiveness and Sustainability Model". Sustainability, 12(15), 5981. https:// doi.org/10.3390/su12155981

26. Pattiruhu, J. R., \& Paais, M. (2020). Effect of Liquidity, Profitability, Leverage, and Firm Size on Dividend Policy. The Journal of Asian Finance, Economics, and Business, 7(10), 35-42. https://doi. org/10.13106/JAFEB.2020.VOL7. NO10.035

27. Qian, Y., \& Fan, W. (2020). Who loses income during the Covid-19 outbreak? Evidence from China. Research in Social Stratification and Mobility, 68, 100522. https://doi. org/10.1016/j.rssm.2020.100522

28. Shen, H., Fu, M., Pan, H., Yu, Z., \& Chen, Y. (2020). The impact of the Covid-19 pandemic on firm performance. Emerging Markets Finance and Trade, 56(10), 22132230. https://doi.org/10.1080/15404 96X.2020.1785863
29. Siegel, P. (2005). Using an assetbased approach to identify drivers of sustainable rural growth and poverty reduction in Central America: A conceptual framework (Working Paper No. 3475). World Bank. Retrieved from http://hdl.handle. net/10986/8945

30. Suratman, A., Suhartini, S., Palupi, M., Dihan, F. N., \& Muhlison, M. B. (2021). The Impact of Psychological Climate and Self-Resilience on Employee Performance During the COVID-19 Pandemic: An Empirical Study in Indonesia. The Journal of Asian Finance, Economics and Business, 8(5), 1019-1029. https://doi.org/10.13106/jafeb.2021. vol8.no5.1019

31. Tan, S., \& Tran, T. (2020). Impact of Covid-19 on firms in Vietnam: Results from the First Round of COVID-19 Business Pulse Survey (Report No. 1). World Bank. Retrieved from http://hdl.handle. net/10986/34580

32. Tran, Q. T. (2013). Livelihood strategies for coping land loss among households in Vietnam's sub-urban areas. Asian Social Science, 9(15), 33-46. https://doi. org/10.5539/ass.v9n15p33

33. Tu, V. H., Can, N. D., Trang, N. T., \& An, L. V. (2012). Tinh ton thuong sinh ke cua nong ho bi anh huong lu tai tinh An Giang va cac giai phap ung pho [Vulnerability of farmers affected by floods in An Giang province and response solutions]. Scientific Journal, 22(b), 294-303. (In Vietnamese). Retrieved from https://sj.ctu.edu.vn/ql/docgia/ tacgia-3790/baibao-5758/doi-ctu. jsi.2012.173.html

34. Tu, V. H., Yabe, M., Trang, N., \& Khai, H. V. (2015). Adaptive capacity assessment of rural out migrants: A case study of an Giang province, Vietnam. Journal of the Faculty of Agriculture Kuyshu University, 60(1), 265-271. https:// doi.org/10.5109/1526321

35. Tuyen, T. Q., \& Huong, V. (2014). The impact of land loss on household income: The case of Hanoi's sub-urban areas, Vietnam. International Journal of Business and Society, 15(2), 339-358. Retrieved from http://www.ijbs.unimas.my/ repository/pdf/Vol15-no2-paper9. pdf 